\title{
Before and after the wheel: Pre-colonial and colonial states and transportation in mainland Southeast Asia and West Africa
}

\author{
Michael W. Charney ${ }^{1}$
}

\section{Introduction}

The resurrection of the abandoned relics of colonial railways currently holds the promise of a revolution in transportation in Southeast Asia and Africa alike, as something good that can come out of the era of European exploitation of the region and the continent, respectively ${ }^{2}$. After all, geared as these transportation systems were to European commercial, political, or military purpose, rather than responding to organic necessity, they collapsed very quickly after colonial rule was over. There, the permanent way remained, scarring the countryside, rusting away as monuments to an era when indigenous political power had been eclipsed. Certainly, the development of colonial transportation infrastructure in West Africa and Southeast Asia is conventionally depicted as an entirely European political, economic, and even cultural intervention that helped to ensure colonial domination that was both a break with the past as well as the foundation for the kinds of states that emerged after independence. The major metropolitan magazines of the high colonial period paraded images of rail lines being cut through African lands in particular with captions that portrayed these as the main conduits of a civilizing imperial power. Little effort, with some notable exceptions, ${ }^{3}$ has been expended on locating within colonial-era transportation networks, the continuity of pre-colonial administrative approaches relative to everyday life in non-western societies. Whether good or bad, or even where they were both, colonial railways, roads, and waterways were viewed as something new and they replaced, or displaced, rather than absorbed, what had existed before, however short-lived they or European rule generally proved to be.

The notion that European rule and influence was brief, shallow, and territorially circumspect has pervaded more recent approaches to the state in both West African and Southeast Asian studies. This is so much the case that scholars have argued, often usefully, against using states as units of analysis or as the best way to frame socio-economic relations. Often the solution is to look at such developments and their historical backgrounds within the

1 The author would like to thank the anonymous referees for their comments and suggestions as well as Tuong $\mathrm{Vu}$ for organizing the panel at which this paper was presented (the EuroSEAS Conference in Vienna in 2015), and Claire Sutherland and Sujit Sivasundaram for providing comments on earlier drafts. The author also owes gratitude to his colleagues in Myanmar who aided in physical examinations of footpaths, roads, and railway routes. The Institute for Advanced Studies on Asia, The University of Tokyo provided research funds for this fieldwork while the author was a project professor there. Thanks are also owed to Osaka University for the opportunity to present some of this research in December 2015.

${ }^{2}$ For Southeast Asia, I am making this point on the basis of personal observation during fieldwork in Burma (as well as in Thailand, Cambodia, and Indonesia). For Africa, see Sturgis (2015).

${ }^{3}$ See, for example, the assertion made by Ravi Ahuja that the railways in India were superimposed upon rather than displacing altogether earlier patterns of land transport (Ahuja 2009). 
context of particular ethnic groups. Such "anarchist histories" in consciously dispossessing the state to get at historical truth, ${ }^{4}$ run the risk of minimizing longer term, yet less visible aspects of the pre-colonial state that were absorbed into and maintained by, in regurgitated or hybridized form, the colonial administrative system. ${ }^{5}$ In doing so, they compromise contemporary understanding of rural economic development, whether by under-estimating the longer historical experience of state influence on mobility, or over-stating isolation from lowland economies. Consider the claim that rural Southeast Asia's emergence out of isolation was due to the mushrooming of road construction since World War II, what Jonathan Rigg calls "a road-building half-century" (2002: 621), or F. Colombijn's observation that "[i]n the past, roads did not play a prominent role in Southeast Asia." 6 These claims provide good examples of where the historical understanding of transportation, movement, and mobility is in need of reconsideration. Despite such claims, roads did in fact play a prominent role in precolonial in Africa and Asia, whose populations, even those living in villages far in the interior, were far from being isolated.

The present article seeks to demonstrate the important influence pre-colonial roads and overland transportation had on the emergence of modern transportation systems in modern Africa and Southeast Asia. To do so, it examines the pre-colonial and colonial transition and the relationship of the court and colonial administration respectively to changing transportation technologies and geographies of movement. It argues that certain pre-colonial attitudes regarding movement, transportation, and traffic had an important influence on emerging colonial transportation networks. The article examines central political attention to mobility, transport, and traffic (or not) and attention to the thinking about the act of governing them (or not) to reveal continuities attitudes that are invisible when looked at through the lens of technological and regime change alone. It is also suggested that these continuities provide one of a number of the inside stories of state formation and change from the pre-colonial to colonial eras in examples drawn from West Africa and Southeast Asia (including Sri Lanka) for the purpose of this paper. Ultimately, these continuities may help to partially explain other aspects of the directions these two examples took after independence.

Rather than the colonial conquest being either a watershed moment or a temporary interruption there was instead a rough continuity in both the state's relationship with and orientation towards mobility, transport, and traffic. Different colonial administrations either encouraged or discouraged movement and transportation, but whichever approach they followed, this was consistent with the pre-colonial practices that had existed before and we can trace the same ways of governing (or not) transportation, roads, and people during the pre-colonial, the colonial, and then the post-colonial periods. In other words, successive polities, whether patrimonial kingdoms, colonial administrations, or modern states, have in

4 One of the most influential of the works of this approach is Scott (2009).

$5 \mathrm{We}$ might be reminded here of the assertion of the editors of one recent volume on the anthropology of state formation that in order to grasp anthropologically the "reality of the state" we need to consider both the state in the form of its imaginary and the state "in the concreteness of practices that have a state relation or reference" (Krohn-Hansen \& Nustad 2005). Arguably, few practices have more of a state reference than the building, repair, and operation of road and the control of their traffic.

6 Colombijn suggests that the relative unimportance of roads was due to the obstruction to road construction of the region's "predominant vegetation type", tropical rains, and the major river systems offering alternative routes of travel (Colombijn 2002). These are certainly valid points. 
particular geographical areas revealed the influence of a particular governmentality (Foucault 1991) towards this particular sphere of human activity that was different than might be found in another geographic, cultural, and environmental space.

Such disjunctures relative to transportation have remained largely invisible because of the limitations of James Scott's concept of state-space, or geographical areas that are topographically and climatologically easily governable, in whose domain transportation infrastructure is conventionally assumed to rest, on the one hand, and the assumption that all rulers wish to do the same kinds of things, namely exert control over geographic areas and people and make then legible to administrative apparatuses, on the other (Scott 1998; Rigg 2002: 619-20). Twenty years ago, John Agnew referred to this theoretical cul-de-sac as the "territorial trap" and identified its responsibility for the framing of the understanding of administrative reach and socio-economic activities as co-terminous with claimed political boundaries (Agnew 1994). Considering transportation infrastructure, in this view, is not necessarily the same as studying transportation within a particular polity or even within the context of state-space at all. More importantly for our purposes here, As Agnew argued, the territorial trap obstructed perceptions of the necessity of understanding the emergence of state-space as a dynamic and historically determined process (ibid).

It the position of the present article that rather than being irrelevant to governmentality regarding transportation and mobility, rulers have since the late early modern period given meaning to such governmentality. They have done so both consciously and unconsciously. Further, depending upon the orientation of this governmentality, this process of giving meaning has occurred when a government either asserts control over various aspects of movement and transportation or when it chooses not to do so.

The research supporting this argument relies upon two main case studies, what are today Ghana (the colonial Gold Coast) and Myanmar (Burma). The Ashanti Empire and the Burma kingdom share many features that make them comparable. The British conquered in the nineteenth century over the course of three wars, starting with territorial loss along the coast in the south. By the mid-nineteenth century, both were of roughly similar size, the Kingdom of Burma being about 190,000 square miles after the Second Anglo-Burmese War (18521853) and Ashanti including roughly 150,000 square miles at about the same time (Murphy 1972; Esler 1996; Keane 2006). In the early nineteenth century, the Ashanti Empire had a population of three million people and just a few years before, at the end of the eighteenth century, Michael Symes estimated the population of the Kingdom of Burma to be three million people as well (Edgerton 2010; Burney 1842). Both of these areas suffered from rainy seasons and endemic insect-borne disease, in the forms of sleeping sickness and malaria in Ashanti and malaria and other diseases in Burma. Politically, both were ruled before the colonial period by kings at the top of imperial systems that ran martial or conquest states dependent on the building of large armies, territorial expansion, and the acquisition of captives. Both societies also viewed their polity in terms of what in Asia would be called a mandala with a center of power at the royal capital surrounded by concentric rings of diminishing central authority, a symbolic representation that was not coterminous with onthe-ground administrative arrangements (Wilks 1976; Wolters 1982). 


\section{Pre-colonial Communications}

Despite the surprising similarities between these two case studies, there were important dissimilarities that had a significant impact on the trajectory of the court or colonial state's developing relationship with people and mobility. For our purposes here, the most important difference was the approach to roads, traffic and movement and this was a result of the different productive basis of each polity.

The pre-colonial history of Burma's road system is neglected because of an early emphasis on the importance of maritime trade in Burma as well as on the sources provided by early Europeans who invariably came on boat and not overland. G. E. Harvey remarked of classical Burma (Pagan) that Burma even had no roads at all (Harvey 1983). Similarly, Maung Shein, whose Transport and Foreign Trade (1885-1814) remains the standard history of transportation in colonial Burma, comments that for the centuries prior to colonial rule, "the natural waterways of Burma, especially that of the Irrawaddy, were the only effective main channels of transport by which goods and people travelled" (Maung Shein 1964: 29). Moreover, Shein asserts,

[r]oads were not very necessary for the traditional self-sufficient subsistence society of Burma. During the dry season bullock-carts could make their way across the country over paddy fields in any direction, making tracks for themselves that could be used until the ground was ploughed up again at the next rains (Maung Shein 1964: 38).

Similarly, in Upper Burma, aside from cart tracks, Maung Shein continued, "from the point of view of trade, it can be said that no roads of importance existed under the Burmese kings" (Maung Shein 1964: 39).

In this view, the British found no real roads in Lower Burma when they arrived and modern overland transportation and government attitudes towards it begin with the British arrival (Ibid). This assumption pervaded the work of J.S. Furnivall and his effort to present the case of unbridled state formation during the colonial period in Burma. For example, Furnivall claimed that Dalhousie

...stressed the importance of [British] road-making and ... ambitious schemes were projected. One road was to be built from Rangoon to Prome ... Prome [was to be linked up] with India by a great highway through Chittagong to Calcutta ... The road from Chittagong to Akyab was reported almost finished within six months of its commencement and by 1854 the section from Arakan to Prome 'was traversible by a horseman at full gallop' (Furnivall 1948: 47-8).

Yet, if we look back at Francis Buchanan's unpublished "Burma Journal" from 1795, written a century and a half before Furnivall (and not having been subject to the same high colonialera notions of colonial economic development), we find that essentially the same road had existed prior to the British arrival in Burma:

[the Myowoon says that] there is a good road by land all the way from Rangoon to Pyee Myoo or Prone. And a road for horses \& elephants from Pyee myoo to Yakhain or 
Arakan in 12 days and from Arakan to Chittagong (I suppose he means the frontier) in 3 days. $^{7}$

Colonial attitudes towards indigenous roads showed considerable difference across the empire, even within the Indian Ocean. The contrast between Konbaung Burma, where the existence of roads has been more completely forgotten, and Sri Lanka where the old roads were seen as relics of a declining civilization that needed to be revived, is quite clear. However, in both cases, colonial engineers made use of indigenous road building, extant paths, and absorbed indigenous knowledge into what became "the bridges and roads that constituted the new colonial infrastructure" (Sivasundaram 2013: 238).

Nevertheless, later historians of pre-colonial Burmese history, by contrast to their counterparts focusing on colonial and post-colonial infrastructural developments, have had a better awareness of the existence of a Konbaung Dynasty-era road network. William Koenig in his landmark study of the Konbaung period remarked that the frequent references to roads in Burmese land inquests and European traveller accounts from the period suggests the existence of a very important system of cart tracks and high roads interconnecting major towns and the royal capital (Koenig 1990: 56). Certainly, our growing interest in pre-colonial Burma's overland trade connections has also underscored if not drawn more attention to the importance of Burma's pre-British road network. A re-reading of at least one royal edict by the present author has revealed statements in the edict not to be merely references to premodern border markers but instead to mark the points at which overland roads reached royal toll stations, where access to this network began or where it intersected with other routes. ${ }^{8}$

One might also argue that portable, universal salvation religions, such as Buddhism, Islam, and Christianity offered to travellers in Southeast Asia (Reid 1993b: 151-79), the kind of protection against local spirits that travel shrines offered in Ashanti. Certainly, this has been argued of Pentecostalism in contemporary Ghana (Bruijn, Dijk, \& Dijk 2001: 75-84), and we might find a similar role in the increased lay Buddhist associations and the provision of Buddhist charms in colonial Burma (Turner 2014).

The existence of roads per se, however, was not the same as an open attitude to popular movement. Attention to the kinds of roads and tracks indicates this in the case of pre-colonial Burma. One kind of road was the royal or military roads. Like Ashanti, Konbaung Burma was a conquest state and had large armies that waged war fairly regularly against their neighbors for territorial gain, captives, and control of trade. The movement of armies was often preceded by both supply men who ensured that supplies of fodder and food would be waiting along the path of the army so that the army would not have to slow down to find them. Of course, there were also woodsmen who cut down trees, built temporary bridges, and generally cleared routes. Campaigns that repeated themselves might follow the same path at least part of the way and as a result, a military road would emerge and would open up a new route for travel for other interests. In Burma, there were several great military roads, such as the royal road in the north, that were designed to carry the great armies of the king on a campaign against an enemy who had been especially troublesome in the past and would thus

\footnotetext{
7 Francis Buchanan, "Burma Journal”, 1795, MSS Eur C. 12, f. 45, British Library Asia and Africa Collection, London.

${ }^{8}$ Royal Order, 27 April 1637 (Tun 1984-1990: 1.265).
} 
likely be so again in the future. A related example might be the An Pass that was cut across the Arakan Yoma mountain range for the Konbaung Army to bring booty back from Arakan in $1785{ }^{9}$

Alongside roads, the Konbaung Army, like its predecessors, also built bridges in the field. Again, bridge building was restricted in both the Ashanti Empire and Konbaung Burma by the nature of the environment, not any technological limitations. Clearly, both could build temporary bridges. There are examples going back to the sixteenth century, of Burmese building pontoon bridges, such as that between Martaban and Moulmein in 1547 that could be taken by a horseman at a gallop. ${ }^{10}$ The case of military roads in Mataram on Java and in Siam would seem to bear out the Burmese example. Such military roads and bridges might then take on a life of their own, as local traders and others found them useful and contributed to the maintenance, repair, or even expansion of such roads without court support. This occurred with the great road through the Arakan Yoma just mentioned. About 1802, it was "improved at the expense of individuals" (i.e. without the support of the throne) so that it could handle loaded carts and thus became a permanent route through the mountains (Symes 1955: 217; Than Tun 1983: 234-41). Additionally, the court or rich donors had a motive to build some bridges and stretches of road on occasion and even to repair them as a meritorious act within the moral economy of Theravada Buddhism in Burma, but these acts were limited in their effects in both geographic reach and regularization of repair (Ba Thann Win 1976: 23).

The Konbaung court disliked the autonomous movement of people on the roads, especially when it meant economically and militarily valuable subjects pulling up stakes and leaving for somewhere else permanently. One of the continual goals of Burma's chronic campaigns against its neighbors was to acquire captive manpower to settle and work agricultural areas and provide royal service. In districts where royal demands became too intense, villagers moved if they could beyond the reach of the court, as was the case with the Mons who left Burma for Ayudhya (today, Thailand) and other areas at the end of the sixteenth century. Trade autonomous of the court also circumvented royal monopolies and taxes and hence was not good for the resources of the court. If the court could have afforded it, it probably would have tried to exert direct monitoring of and control over the roads, but the nature of the Burmese environment would have prevented this anyway. Much of the Burmese heartland was flat and dry and easily traversable on buffalo carts, even off of the tracks and roads. In wetter areas of the kingdom, such as the Lower Burma delta, the overgrowth was not nearly as impenetrable as the West African jungle and any road controls in the former would have been easily circumvented. Instead, the Konbaung court focused on the only feasible, costeffective means of controlling, monitoring, and taxing movement, by controlling access points to external trade, both overland and at sea, at the ports or major land crossings, or where land routes linked up with river ports. Thus, the autonomous myriad of local roads remained outside of their reach in a practical sense even if the political centre's desire to control it continued. There is thus little evidence of roads being cut by the Konbaung court

\footnotetext{
9 In 1784/5, the westernmost Southeast Asian kingdom of Arakan (Rakhine) was conquered by Konbaung Burma's armies and incorporated into the Irrawaddy-valley based kingdom.

10 "Nidana Ramadhipati-katha". Translated by H. L. Shorto. TMs [photocopy], private collection, Dr. Victor B. Lieberman, Department of History, University of Michigan, Ann Arbor, Michigan (n.d.): f. 47.
} 
for the explicit purpose of encouraging or controlling trade (rather than for military or political purposes). These emerged independently of the government, on the logic of trade exchanges and were usually more worn between large population centres than between small ones (ibid). These were sometimes only paths that emerged cross-country, forged organically by the movement of traders who had no immediate access to the river. In Burma, there were also highlanders who came down to the lowlands and from the eastern hills to feed markets at the river ports where they would then enter a system of circulation run by the lowlanders themselves. All of these popular movements converged in a way that made the flow of traffic almost like a river, as described by Nisbet at the end of the nineteenth century about the earlier, pre-colonial era:

[I]n former times, before the era of road-making, the country carts had to be so constructed as to be capable of traveling over very rough ground. The cart- tracks began in the fields whence the grain was brought on sledges or carts to the hamlets and villages, and gradually those single threads converged to form the main lines of communication, as small tributary streams are gathered together in the main watercourse (Nisbet 1901: 1.376-377).

With the exception of special cases, such as the construction of a military road as mentioned above, the Konbaung Kingdom, by contrast to the Ashanti Empire was not a road- building project. Very clearly, in this case, roads followed the empire and not the reverse.

One consequence of the pathways and roads in Burma not being government roads was that they, like much of overland travel in mainland Southeast Asia, suffered from the depredations of highwaymen. Robbery was a significant problem for overland travellers in early modern Southeast Asia (Nisbet 1901; Reid 1993a: 54, 57-8). Indicating the absence of government protection and the reliance on locals to help, robbery was more common in "thinly populated regions of the country" than in better-populated areas (Anuman 1987: 173). The chief strategy to fend off highwaymen was for travellers to move about in cart caravans (Anuman 1987: 173; Reid 1993a: 58). The customs posts that stood at control points in some parts of Southeast Asia as in Java (Ibid; Reid 1993a: pp. 53-4, 58), were not maintained as thoroughly in Burma. This was because, as I will mention again below, it was easier to collect revenues and fees further down the transportation chain on the river than on land, given the numerous opportunities overland travellers had to circumvent any such customs posts on flat country.

Moreover, the Konbaung Kingdom developed no central infrastructure for road repair. Burmese accounts and traveller accounts alike speak of Burmese military roads as not being maintained by the court. A good example is that of the Ba Daung Taung Goke Road examined by Than Tun. Than Tun notes that although it was the historic conduit for intercourse between the Irrawaddy Valley and Arakan, was, at least until 1783, in poor shape. It remained a difficult track, unsuitable for carts, and lacking supplies of water along the course of travel, making the use of baggage animals difficult. Certainly, road maintenance here was much more neglected than the road's counterparts in Ashanti. Here, there was nobody keeping up the road (Than Tun 1983: 239-240).

One reason for the apparent neglect of the roads by the Konbaung Kingdom was the existence of the great Irrawaddy River. Admittedly, the Konbaung Kingdom lacked the 
technology to conduct major river works, but the scale and capacity of the river did not demand it anyway. It was easy to rely upon the river for maritime trade but also to control trade that might feed the overland trade with China once it got there. By contrast, the onerous task shouldered by the Ashanti Empire to maintain the roads, the river made traffic management much easier for the Konbaung Kingdom. The idea that Konbaung Burma would have to invest in general travel outside of its own direct needs does not seem to have emerged. The shallow entrances to the Irrawaddy River meant that heavy draft European ships had to be piloted in carefully and the Konbaung Kingdom, which garrisoned Syriam and Bassein, was able to control access to the river system, the enforce rules that required Europeans to leave their guns and masts at Syriam before entering the river (Charney 1997: 61). Like Ashanti, Konbaung Burma had a customs administration and a military force that controlled the interface between the domestic communications system and the outside world. Most customs outposts or kin were located on the international frontiers or on the access points to rivers, but not on domestic overland routes. There were also checkpoints on passes going up into the hills for overland travel that worked in a similar way. But, in both cases in Burma, river and overland travel, the court did not invest in the actual transportation infrastructure.

Another reason for the Konbaung neglect of roads was that much of the economy was based on sedentary wet-rice agriculture and rather than capture people to sell abroad, Burma needed its war captives to open up rice fields and engage in other economic tasks. These resettled communities would play an important role in influencing Burmese culture and society, but also circulating technology, as historians like Bryce Beemer have recently shown (Beemer 2004). Rather than encourage mobility and movement as Ashanti did, Burma fits more closely the idea James Scott seems to have had in mind when he asserted that grainproducing states do not like mobility. Instead, they prefer a fixed, sedentary population, not just one that remained within the royal domain, but one that remained tied to the locality, mobility being used, in Scott's view, by nomadic peoples as a tool to evade the central control (Scott 2009: 184-5). In Konbaung Burma, there was no effort to encourage overland or riverine movement per se, nothing to expand flow, enhance capacity, or speed up everyday popular traffic. In other words, there was no elaborate logistical theory or methodology.

Nevertheless, there were a myriad of controls on movement and mobility and no resources put to their disposal. These controls have been extensively researched elsewhere for precolonial Burmese history and do not need to be discussed at length here. What is found in the Burmese and English language sources is a range of the aforementioned social controls that provided a proto-administrative or political obstacle to movement rather than an economic one. This oversight prevented previous scholars from identifying in pre-colonial rule in Burma a pre-existing administrative desire to limit mobility prior to the introduction of the British colonial state.

The most important pre-colonial Ghanaian polity, the Ashanti Empire, could not have had a more different attitude to non-state mobility and transportation. The Ashanti focused not on sedentary agriculture, like many of the more popular examples used as case studies of state formation in the non-western world, but on commercial traffic that ran through the kingdom, the gathering of surface deposits of gold for export, and the capture and sale of slaves, at least until the mid- nineteenth century. The great road system built by the Ashanti has been 
covered extensively in the historical literature, in particular by Ivor Wilks (1975). From the beginning of the eighteenth century, the Ashanti Empire had rapidly expanded on the basis of a particular take on the West African imperial model. This take involved developing roads that emanated out of the royal centre at Kumasi and either negotiating with local chiefs or conquering them when negotiations failed to construct further extensions of these roads until they could reach a point at which they interconnected with existing trade networks (a good example would be pushing a plug until it reached a mains). The empire's boundaries became coterminous with the furthest extensions of these "great-roads." The growth of Ashanti was directed at this kind of road building.

Quite literally, the Ashanti Empire grew as a road-building project, empire following the road, rather than road following the frontiers of the empire. The reason for this phenomenon was that the Ashanti sought to benefit from the movement of trade through the empire and thus pushed out politically to link up with trade routes whenever new ones emerged or old ones shifted. Administration was introduced as a result of this expansion as the cutting of roads required political negotiations. This produced a model of imperial growth in which opposition to that growth was manifested in opposition to road-building projects. As Wilks has commented,

A full history of the great-roads of Asante remains to be written. But it will be apparent that the development of the system was a critical aspects of the incorporative process. Indeed, opposition to the central government's road building programme was one of the principal features of the syndrome of resistance to its imperial expansion, just as the closure of existing roads became one of the earliest indications of rebellion (Wilks 1975: 25).

As described by Wilks, the great-roads of Ashanti were the "conduits of authority" beginning at the capital and ending at the frontier. Importantly, how the Ashanti imagined the boundaries of the empire was not coterminous with its exact delineation on a map built around western cartographical principles. The mental map of the Ashanti kingdom, the positioning of territory, was a series of concentric circles emanating from the center on the basis of how much territory a man could cover in forty days, a homologue to use Wilks' phraseology of the Ashanti month of forty-two days. Nevertheless, this indigenous imaginary did not reflect western cartographical representations in the south. Instead, the mental map fairly approximated the interior land frontiers of Ashanti. This was

... a rational recognition of reality: that without any major change in the speed of communications, no lands more distant than a month from Kumasi, in and out, could effectively be administered even though they might be subdued for the duration of a campaign (Wilks 1992: 182-4).

Thus, the regular reach of the court was more circumspect than the temporary and potential reach of the military. Arguably, the fiction produced by relating Ashanti state-space was a western map as a large circle shaded in equally across its diameter would have been no less accurate than colonial entities delineated on maps of Africa after the Congress of Berlin. In both cases, state-space hugged the main arteries of communication, an observation in keeping with the argument of this article. 
Before Ashanti's great-roads were built, travel had to be along streams as the bush was said to be impenetrable (Wilks 1975: 29). Ashanti's "great roads" were built from the early eighteenth century to make cross-country travel less arduous and time consuming. An artistic representation of one of these roads can be seen in Figure 1. Political obstacles lay in the way whose resolution contributed to Ashanti state formation. When the Ashanti attempted to open a road in the second decade of the 18th century, from Kumasi to Elmina and the western coast, for example, they found the project compromised by shifting alliances with the chiefdoms through which the road passed. The Ashanti thus proceeded to conquer such chiefdoms and force their leaders to submit to Ashanti overlord-ship in a series of wars between 1715 and 1721. The Ashanti followed this in the 1740s by conquering Akyem in order to open a great road through Accra and to the eastern coast (Wilks 1975: 24).

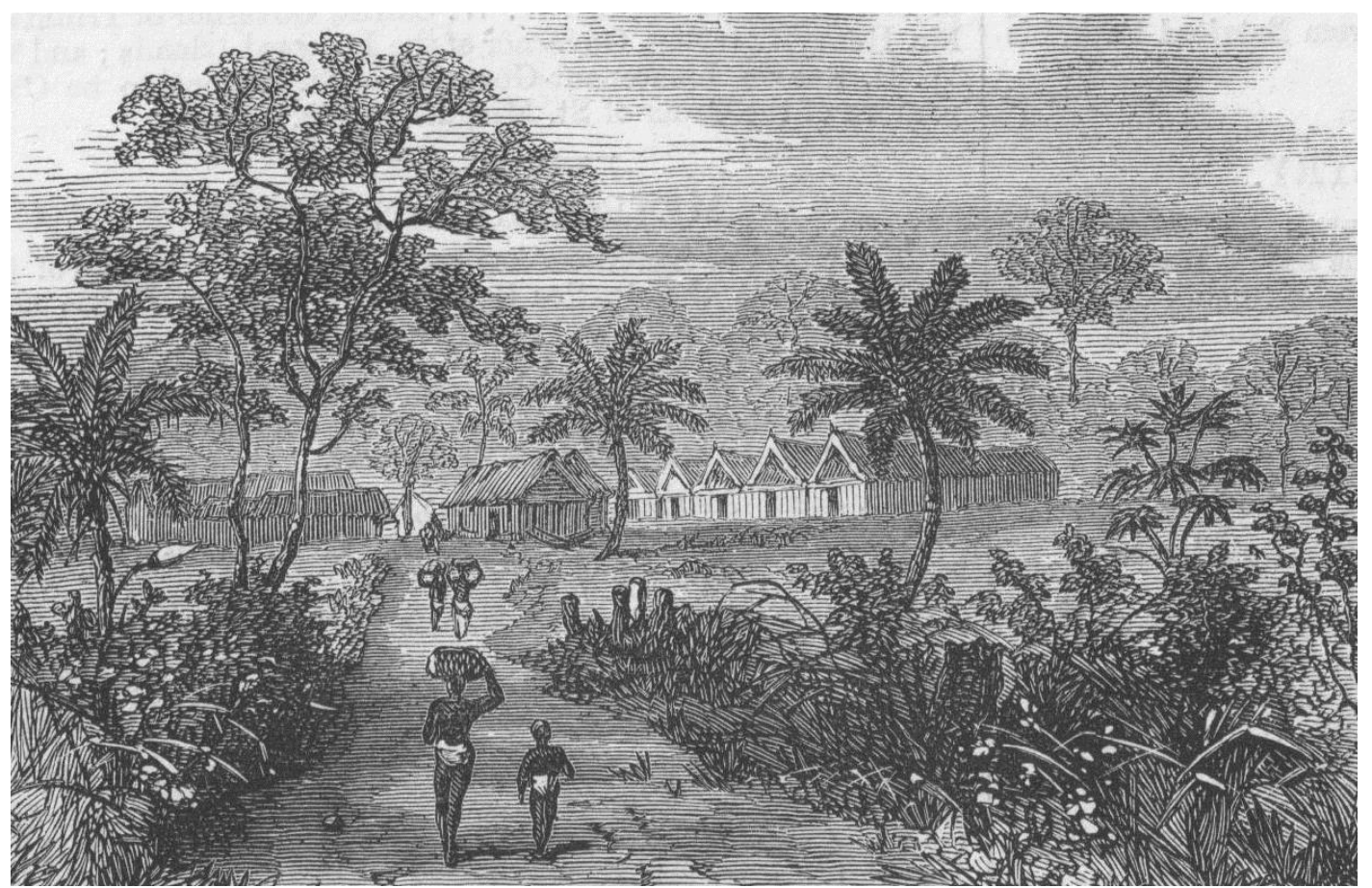

Figure 1: Illustration of Road Travel in Ashanti published in the 'Illustrated London News', 28 February 1874 (Author's collection)

The Ashanti Empire also maintained sacred roads (and these were not inclusive of the entirety of pilgrimage routes). The distance between boat landings or road heads and sacred temples of the tombs of ancestors received special attention, including a ban on their use independently of their sacred function. A good example of this was the one-mile road between the Ashanti capital of Kumasi and the sacred town of Bantama, which the king visited every forty days in the mid-19th century in order to visit the tombs of his ancestors (Freeman 1844: 57). This was the location of the blackened stools of past Ashanti kings (Perbi 1992: 79). The population was only able to use this road when the king did so (Freeman 1844: 57). Such roads received special attention from the court, often being cleared regularly, leveled, lined with trees to provide shade, and even surfaced with stone.

Aside from the sacred roads and roads in the royal capital, the technology and ability to surface or level roads and to bridge rivers did exist. This engineering capacity was clearly applied on special occasions, but the court could not afford to do so on a regular basis to the 
same degree as a modern state. This was due to the environment. Ghana, like Burma, experienced heavy seasonal rains, the washing away of roads and bridges, and the clear if unpronounced logic of any cost benefit analysis made regular royal investments seem unwise. The impact of these rains on the roads outside of the towns, even within some towns outside of the royal capital, and even within the royal capital outside of the city centre is captured in the words of one mid-nineteenth century traveller to Ashanti:

some of the streets are so full of holes, occasioned by the heavy rains washing the earth out of the fissures of the rocks during the rainy season, that any one attempting to walk through them in the dark, would place his neck in danger (Freeman 1844: 55).

Even where roads were not washed away the rains greatly hindered movement, porters slipping constantly, dropping bags, and being unable to care elite people in the chairs on their shoulders (Freeman 1844: 63). When the rains stopped, vegetation remained a problem. The predominance of jungle and rain forest foliage and the infamous creeping vines made roads often impassable without considerable effort by the traveller.

Road maintenance and clearing outside of the royal capital and sacred roads still remains an underexplored topic in the historiography. According to British military reports in the $1870 \mathrm{~s}$, the indigenous population used these roads "as a latrine, and as a convenient place of deposit for all rubbish" (Brackenberry 1874: 1.315). The fairness of this description is questionable. The technologies and scale of labor of the day could only take care of so much and unless a "problem" was relevant to foot travellers, it was not a problem that needed to be handled. It was clear for example, that the Ashanti did take care of the roads. Freeman, for example, in his 1841 journal of his travels between the Gold Coast and Ashanti does not refer to foliage and overgrowth being a problem on the Ashanti side of the Prah River. However, once he crossed to the Fanti side, the road became impassable, Freeman relating that it was "so overgrown with luxuriant vegetation, that I was literally dragged through the bushes, and was soon compelled to walk" (Freemen 1844: 67). On another occasion when approaching the Prah River from the Fanti side again, "The road also was exceedingly bad, being in many places not more than nine inches wide, full of wholes, and roots of trees rising above the ground" (Ibid: p. 16). This difference seems to suggest that the Ashanti Empire was indeed much more active than Fanti in road maintenance.

On one occasion, an Ashanti king cleared a road on behalf of a foreign missionary. In this case, the king dispatched men to clear fallen trees from the road to open the way for the passage of a carriage to Kumasi. Nevertheless, the missionary claimed that the stumps and roots of trees were still a problem on the rest of the road. This is difficult to read precisely, but it probably refers to the more regular condition of the road itself, which, again, historically would have hosted travellers on foot, not on wheels and hence stumps and roots were never an issue until now (Ibid: p. 102). This suggestion is borne out by complaints by British army engineers in the Ashanti War in the 1870s who commented:

The falling of trees across the road was also a constant difficulty; not one of the least obstacles to progress being the need for cutting through their enormous trunks which lay across the road and barred the path. Some of these trees had trunks of hard wood, 
Mahogany and iron-wood, 4 or 5 feet in diameter; and of course the appliances for cutting them were limited (Brackenberry 1874: 1.315). ${ }^{11}$

One of the most revelatory aspects of Ghanaian and Burmese historical culture, noted in traveller accounts from the pre-colonial period was a more reserved and even hostile attitude to foreigners in Konbaung Burma than comparable travellers found in Ashanti of the same time and this was especially true of the main cultural core of Ashanti. As Iver Wilks has suggested, the "foreigner" as an abstract category was considered with less hostility in the Akan (the base population group of Ashanti) world than might be the case in other societies, such as that of Burma. The Ashanti Empire was built on encouraging mobility and in fact its wellbeing depended upon it. Wilks pioneered the study of the "great-roads of Asante" in his 1975 monograph and related work. It would be useful at this point to summarize Wilks' sketch of the Ashanti administration of transportation and movement in the pre-colonial period. As Wilks shows, an economic motive was not the only factor in influencing Ashanti administrative approaches to their road network. The scope and speed of travel determined the territorial structure of the Ashanti Empire. Wilks, referring to a minimal message-delay, explains that the ability of the king's messengers to reach a certain point after so many days, determined what was centrally ruled (the royal capital to the metropolitan regional boundary six to twelve days). Outside of this circle was an outer concentric ring of inner provinces (one month from the capital), then frontier districts (five to seven weeks). Further out was territory where "the exercise of political control ceased to be realistically attainable" and so outside of these were "adjunct territories" and then foreign polities (Wilks 1975: 61). An elaborate administrative apparatus was developed to maintain traffic and royal revenues on the greatroads rather than regulating domestic access to the roads or domestic movement. The akwanmofo managed traffic facility - it repaired roads, mobilizing villagers, using free and paid labor, in the vicinity to do the work, and generally sought to remove obstacles to free movement on the Great Roads. Another administrative unit, the nkwansrafo (the king's pathkeepers or highway police), garrisoned control points on the routes close to the frontiers of the kingdom to monitor the flow of commodities and extract customs duties, being quite literally a force that enforced the control point as customs house. The actual garrisoning of the road was only done at control points where the great-roads intersected with on-going maritime or overland routes (Wilks 1992: 175; Wilks 1975: 17, 49, 55). Importantly, the Ashanti Empire did not attempt to restrict travel on the roads beyond extracting customs or preventing entrance by hostile forces.

The Ashanti Empire instead ensured that materially and spiritually travellers were protected from the environment, the gods, and other bad-meaning people. The court also established a number of halting points explicitly for the purpose of providing shelter and sustenance for travellers on the way to and from Kumasi. Complementing the court's patronage is this regard was the more autonomous erection of travel shrines. There was the danger for travellers that they would anger the High God of Ashanti or local family gods. In Ashanti this was resolved by circumscribing a special space for foreign travellers that meant

11 Claims that the indigenous population pulled such trees down over the road on purpose appear to be misinformed. 
they would not anger these gods and travel shrines were erected that protected the travellers along the great- road they were on (Wilks 1975: 25).

Thus, comparing pre-colonial movement on Burma and Ashanti provides us with very great contrasts regarding movement and mobility. Scott suggests for the comparativist "a gradient of mobility, from a relative frictionless ability to relocate to a relative immobility" (Scott 2009: 184). We might find Ashanti sitting somewhere very close to the frictionless end and Konbaung Burma much closer to the mobility side of the scale.

\section{The Intermediary Period of Multiple State-spaces}

In the intermediary period between pre-colonial kingdoms and colonial states, new means of transportation entered the indigenous mind-set and foster new thinking about motive power, movement, and speed. From West Africa to the Java, a swathe of pre-colonial kingdoms was being cut up an annexed in pieces as part of a gradual process of European conquest. The slow progressive nature of this process meant that for decades various societies in Africa, South Asia, and Southeast Asia had a mixed period in which such areas had both a precolonial kingdom and a colonial state with pretensions to the other.

This period was important as a learning phase for both indigenous courts and societies and European administrators. Intellectually, the period saw the inroads of European ideas about transportation and related technology. New means of transportation were very vigorously promoted not so much by one government to the other but largely by other agents who did so for different reasons. These included locomotive manufacturers who sent samples, missionaries who were proffering progress and "civilization", and even rival governments that sought to obstruct expanding British influence in both cases. As one such agent recorded, "Our [c]arriage [a gift to the king from the Wesleyan Missionary Society] is the cause of a better road being made through this part of Ashanti, than has ever been seen before... good roads greatly promote civilization" (Freeman 1844: 119).

Before the extension of colonial rule, stories of new forms of transportation reached the ears of the kings of Burma and Ashanti from merchants and missionaries. In both cases, special examples of the new kinds of transportation were provided to these kings, which aroused awareness in him that their incorporation would require infrastructural change. The King of Ashanti was reportedly "very much interested and astonished" in 1841 when informed of the rapidity of travel permitted by railroads and steam-packets (Freeman 1844: 132). Further, when the same king received a gift of a carriage, the first in the royal capital, he found he had to undertake works within the confines of the royal capital to make use of the gift. The streets in Kumasi had to be widened and cleaned and new streets even had to be built. A letter of gratitude to the missionary society reported the king's happiness that he would no longer have to burden his countrymen with the onerous activity of carrying him around on a chair (Freeman1844: 86). New technologies of transportation also seeped into the Burmese kingdom from the colonial areas as well. These had the effect that like the carriage in Ashanti, the locomotive in Burma was also influencing indigenous people about the new possibilities of transportation even before they arrived. This is evidenced in painting murals 
on the southern approach to the Mahamuni Shrine in Mandalay, which can be seen in Figure 2 , and the inclusion of steamships in Jataka Story murals produced during the period. ${ }^{12}$

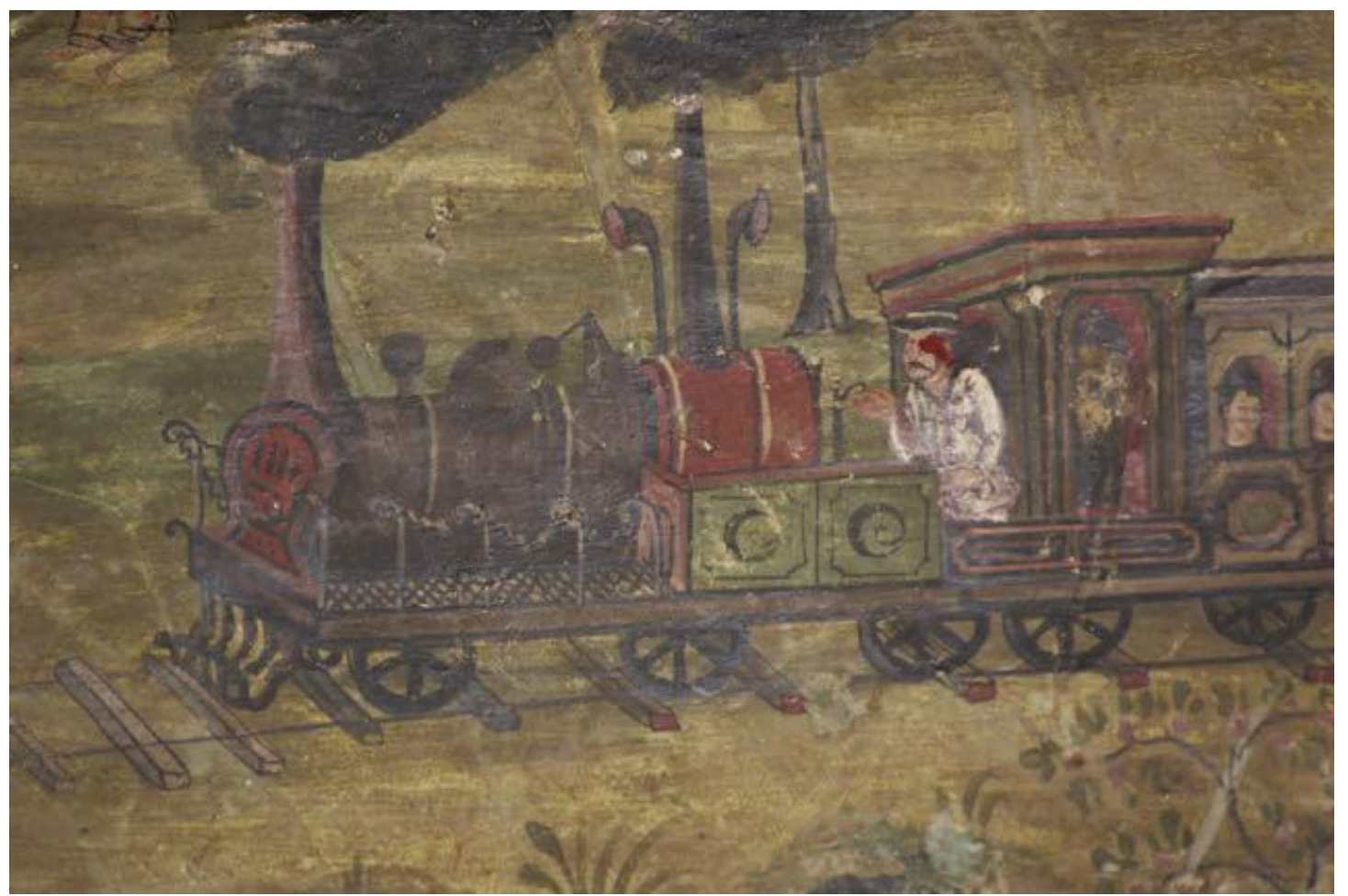

Figure 2: Mural of Train in Upper Gallery of South Entrance of Mahamuni Shrine at Mandalay (Photograph by author)

Local road building during this period was also a learning experience for Europeans across Africa and the Indian Ocean in the early 19th century. Herman Willem Daendels, the Governor-General of Java (1808-1811) is of course famous for the Great Post Road he built across Java (Doormont 2001: 15). Daendels' effort was commercial, to link up interior products with Batavia, but it was political as well for where the road went, Dutch administrative and military control was strengthened. Like the road in Java, the great military road from Colombo to Kandy in Sri Lanka was a political contest, as Sujit Sivasundaram explains, to assure British authority and it consumed a decade's worth of Governor Edward Barnes' efforts to bring the road up the hills to the mountain city. As Sivasundaram shows, the British road-building project was built in communication with indigenous approaches to the roads both real and imagined. On the one hand, for example, the British made use of the rajakariya, the indigenous forced labor system, to build the road, and, on the other, undertook some initiatives, such as digging a particular tunnel (at Kurunegala) because this act would satisfy an indigenous legend that their political authority would only be assured when the tunnel had been made (Sivasundaram 2014: 227-231). In other words, it was not only the indigenous society that had to adapt to western innovation, but the westerners who had to listen to what indigenous societies thought was important about transportation.

12 These comments are based on personal observations the author made of the murals during fieldwork in Mandalay in June, 2014. 
Even so, Europeans were credited with all road building by several generations of scholars working on the colonial period The aforementioned Daendels, who later found himself as Governor-General of the Dutch Gold Coast (1816-1818) and died there of fever in 1818, is a good example of this faulty attribution. Daendels had planned to build another such road connecting Elmina and Kumasi, but this was not begun before his death (Doormont 2001: 15). The implication is that Daendels was introducing something new, but from the Ghanaian literature and the preceding history of road building it is pretty clear that he was going to add his road to an indigenous network already in place over the course of the preceding century. The Ashanti War almost gave Ghana what would later become its first railway in the early 1870s. ${ }^{13}$ The Commander of the campaign, however, reported back that there was no time to lay a railway and so the material sent remained offshore and was never landed and the orders for more materials were countermanded. This made the completion of a road more important than it might otherwise have been (Brackenberry 1874: 1.309). But it also meant that the introduction of the railways would come during the phase of full colonial rule. Hostility at the frontier of Ashanti and the Gold Coast after the war of 1873 eradicated their interface at the frontier as a node in commerce with serious implications for trade in the southern portion of the king and thus the viability of the road network in this area. The commerce that formerly flowed down via the Great North Road through Ashanti to the Cape Coast ceased as the Ashanti Kingdom broke up and smaller, hostile chiefdoms emerged on the political terrain forming together an "impassable barrier" (Freeman 1898: 485-6).

Trade now diverted away, from the north of Ashanti to the French Protectorate and down to the Coast of Assini and the Great North Road "rapidly degenerated into a bush-track" (Freeman 1898: 485-6). Roads within the Cape Coast in the early years of British rule fell into what was viewed by British engineers as serious disrepair. Rains had washed out parts of some roads, others were overgrown with vegetation, and some stretches were merely lengths of the beach. The main element that defined much of these roads as indeed being roads was that trees had been cleared up to fifteen feet across. Early recommendations were to construct drains along the roads. ${ }^{14}$ The British must have brought the condition of the roads under control for Wilks explains that when political opinion in Ashanti divided over whether it was worth holding onto resistant southern provinces, the majority went with the policy of surrendering their control to the British, because they now kept the roads open and in repair to the benefit of the entire Ashanti road system (Wilks 1975: 29).

British efforts to build bridges fared just as poorly in Ashanti and Burma as other roadbuilding efforts fared in Sri Lanka when countered by the adverse environment, particularly the monsoonal rains. The Kandy Road in the latter case washed out twice a year, metalling the road was not even attempted until 1841, and the tunnel collapsed in 1849, forcing the road engineers to add another two miles of road skirting the mountain instead of going through it. Sivasundaram's observation that Europeans of the period were having difficulty "apply[ing]

\footnotetext{
${ }^{13}$ In expected support of the military campaign, the War Office had dispatched a complete tramway, including a traction engine, 6.25 miles of track, and some trucks on transports and orders had been put in for more material as well (Brackenberry 1874: 1.309).

14 R. Lonsdale, "Memorandum of Prince Buaki's Journey from Elina to Accra, with Notes on the Condition of the Roads, etc, 13th to 22nd September 1881", in House of Commons Command Paper 3386, "Further Correspondence on the Affairs of the Gold Coast", p. 4.
} 
their science to the tropical environment" (Sivasundaram 2014: 228-229), holds equally true for this intermediary period in the case of West Africa (Ghana) and Burma. As all travel in Ashanti was on foot and bridges were expensive to build and difficult to maintain for environmental reasons, any cost- benefit analysis would have cast doubt on the viability of extensive bridgeworks as opposed to the use of ferry canoes across rivers and streams. The court also did not normally invest in bridgeworks. In part this was likely because as all travel was on foot, bridge works would not have mattered significantly anyway given the availability of ferry canoes for river crossings (Freeman 1844: 17). Further, during the rains, rivers expanded dramatically and in delta areas even changed course from year to year (Brackenberry 1874: 2.237. 245). In such conditions, bridges could only be temporary, built for purpose, and of quickly gathered materials that were relinquished to nature afterwards or otherwise removed. In 1841, Freeman observed the building of temporary bridges on the order of the king for the passage of the gift carriage (Freeman 1844: 118). These bridges were, he explained,

the...first attempts at making bridges I have seen in the interior. They are constructed in the following manner: some stout, forked sticks or posts are driven in the centre of the stream, at convenient distances across which are placed some strong beams, fastened to the posts with withes, from the numerous climbing plants on every hand. On these bearers are placed long stout poles, which are covered with earth, from four to six inches thick; and this completes the bridge. ... (Freeman 1844: 118).

The cultural legacy of this was that the "bridge" in the indigenous view was not a permanent structure and its materials were free for re-use after its immediate purpose was over. This led to situations that horrified British army engineers in the Ashanti War as their indigenous allies ripped apart the bridges they had just built. As one engineers recalled: "I find ... that much injury is done to the road, bridges and fascines over swamps by the native allies, who tear up the bridges for firewood, and pull out the fascines for the same purpose" (Brackenberry 1874: 1.315). This thus hindered the influence of bridgeworks for some time. In support of the "strategic road" constructed into Ashanti by Royal Engineers during the Ashanti War 237 bridges were built (Brackenberry 1874: 1.316). The British destroyed at least some of these bridges themselves, including the bridge over the Prah River, when they withdrew at the conclusion of the Ashanti War (Brackenberry 1874: 2.276). The other bridges left intact fared poorly over the following decade and a half, most being in an "advanced state of decay" or disappearing altogether and some replaced merely by a $\log$ thrown over the stream (Freeman 1898: 25).

It took until the Campaign of 1873 for the British to be able to demonstrate that they knew how to build a road just as well as could the Ashanti. In preparation for the march of the British Army into Ashanti, British military engineers went to work putting the roads into a condition that would permit the advance of a European army in stages in reaction to changing events. Prior to the arrival of the commander, Lieutenant Gordon had made road up to Yancoomassie Fanti but only so far as clearing a path of a width sufficient for movement the road surface was not yet suitable for the march of soldiers and artillery. To achieve the latter, Major Home and the Royal Engineers were tasked with widening the road to twelve feet, clearing all stubs and roots, draining the swamps or building causeways through them, 
building culverts, and erecting bridges over all streams (Brackenberry 1874: 1.310). The "strategic road" thus built remained in good condition fifteen years later when another British expedition passed over it in 1888 (Freeman 1898: 25).

Attention to this intermediary period is important for two reasons. First, it demonstrates that European technology was not a 'shock' package that was introduced by colonial armies on the completion of conquest. Rather, European transportation technologies were wellknown and often rejected long before colonial rule was cemented, at least completely, after a period when indigenous courts and societies weighed and rejected or neglected what was on offer. Second, such failures often meant that while Europeans awaited advances in technology that would be better suited to West Africa and mainland Southeast Asia, they had to engage with what transportation networks were already in existence.

The slowness of change impacted both the political centre's approach to movement and the relationship of users, the people, to movement in several ways. Religious pilgrimage, an exception to royal restrictions on movement in Burma, saw the introduction of religious amulets, some of them being miniature replicas of the Mahabodhi Temple and Buddhism, as a universal salvation religion offered protection beyond the locale as mentioned earlier. Regarding road travel, however, the erection of nat-shrines, to propitiate local spirits, may have been more important. In pre-colonial Ghana, this protection had come from the king, but the slow introduction of colonial rule and separate spiritual fields in the north and the south during the intermediary period allowed for the religious accommodation of mobility in Ghana. Protection of travellers would come from spirit-cults introduced by northern migrants into Ghana, often focused on "anti-witchcraft shrines" built alongside the roads (Klaeger 2009: 227), in a manner similar to nat shrines. These spirit cults were then copied by southerners that were then established in the north as well, providing protection for both mobile populations (Bruijn, Dijk, \& Dijk 2001: 79-80). As Klaeger (2009: 231) and Ntewusu (2014: 15-7) have shown for contemporary Ghana, this kind of spiritual protection over Ghanaian travel has permeated the road system itself, so that not only are road accidents seen as the result of negative spiritual activity, but the act of road-building requires ritual and ritual specialists to investigate and undertake the work.

The slowness of the introduction of European transportation also meant that the evolving colonial states were influenced at least indirectly by the existing condition of transportation in Ghana and Burma and with this influence, it is suggested, came certain orientations towards the management of popular movement and travel. It is also possible that the same constraints and opportunities that shaped pre-colonial attitudes towards free or control movement would have similarly influenced the colonial state to adopt the same perspectives. In either case, there was good reason for continuity in governmentality towards transportation and movement. This continuity will be explored in the following section.

\section{The Colonial Period}

A good deal of the literature has viewed the colonial state as an external imposition that differed from the patrimonial kingdoms and chiefdoms they encountered and conquered in both Africa and Asia. Some literature has seen the colonial state as an interregnum and have viewed the military regimes that began to sweep Asia and Africa from the 1950s, all 
succeeding earlier, failed civil democratic experiments, as representing a return to the precolonial African and Asian ruling elites' reliance on military force for the extraction of resources. ${ }^{15}$ Some scholars have seen continuity through the entire era of the colonial experience. Although regime change indeed took place, it is observed, colonial states commonly introduced mixed administrative systems in which traditional institutions were curtailed but maintained alongside "modern" governance systems as part of divide and rule policies. Other scholarship on Africa has gone further and argued that European role was so short-lived and so negligible in its penetration into the interior that the colonial period left weak national institutional structures and a poor network infrastructure. This mixture of authority often survived independence, contributing to the stability of central rule in some former colonies and to political instability in others, Myanmar and Nigeria being two major examples where this legacy has resulted in major civil wars (Michalopolous \& Papaioannou 2011: 1, 5).

However much colonial states ensconced themselves in the vocabulary of modernity when they put their faith in the importance of new steam and then gasoline technologies, they were still strongly influenced and shaped by the pre-existing court approaches to transportation and the transportation networks. Rather than writing new transport networks on a blank sheet, these colonial states in both Ghana and Burma were slow introductions that gradually absorbed what was already in place. New colonial transport systems in these cases were actually hybrid systems that grew in a conversation with pre-existing road and river networks and with the cultures of royal control over traffic that long predated the arrival of Europeans. Local European traders, administrators, and engineers found they would have to deal with these constraints and opportunities if they were going to make significant headway. The colonial state's approach to transportation in both Ghana and Burma was realized through a pre-existing indigenous framework.

More generally, in both Ghana and Burma, the existing roads did not disappear as routes. In Ghana, the old great-roads of Ashanti were to become the foundation of new motor roads that were built over them. In the early twentieth century, the great-roads were no longer functioning as great-roads, but they were still there physically and the system of travel they sustained would largely continue on to the present; two-thirds of the great-road system becoming motor roads (Wilks 1975: 13). As motor roads, the old great-roads interconnected with paths and side roads that generally kept the Ashanti transportation networks intact. The railways of the Gold Coast focused on the maritime port trade and especially that which served the gold mining operations and not the general economy. In Ghana, alternative options of travel meant that Ghanaian autonomy of movement and with it political autonomy, saw continuity, while simultaneously, European dependence on the railway for mining and other forms of resource extraction meant that West African colonial states became increasingly vulnerable to African economic and political empowerment movements partly derived and supported by the organizational power of the railway's labor union as well as those in other strategic industries, demonstrated in the form of railway strikes early in the postwar period, first in Nigeria in 1945 and then in Ghana in 1947 (Jeffries 1978; Cooper 1992: 21). 
Although railway extensions would be built from the 1920s these never really escaped competition from the roads. The first permanent road bridges and better roads built in Ashanti and the Gold Coast were for bicycles. Some District Commissioners there were doing anywhere from 32 to 45 miles in a day on their bicycles on their rounds and the bridges and roads made these journeys much less onerous and faster than they might otherwise be. From 1915, such work began to be conducted on motorcars, especially on the Ford Model T, making bridges or at least heavier duty river ferries indispensable (Williamson 2000: 9).

When the British entered their last stage of expansion in Burma in the Third AngloBurmese War (1885) and the subsequent pacification campaign, roads were essential for establishing their control and assuring tight administration. As the Burmese royal roads, the kingdom's military roads had been arranged with military reach in mind, they were well suited to adaptation to British needs. In 1886, in the Mandalay area alone, the British reformed (rather than construct afresh) fifteen miles of road, metaled them, and rebuilt the existing bridges. Outside of these roads, the British also turned partially to finishing some two hundred miles of country roads. Where other routes of passage were necessary, such as between military outposts, the soldiers themselves cleared jungle and forest to form temporary forest tracks of about one hundred feet in width (Croswaite 1912: 67).

Like the pre-colonial Burmese kingdom, the colonial government saw the Irrawaddy river network as western Burma's transportation artery, a main thoroughfare of great capacity, access to which in an out could be controlled by the military and monitored and taxed by the customs administration. For the landlocked eastern part of the country, the British saw the railway as best alternative to the Irrawaddy and the IFC. In building the railways, though, the new railway lines were laid on top of the old road beds (the first being the roads from Rangoon to Prome and from Rangoon to Toungoo) and as these roads always had in the past, the railways now built on top of them linked up with the river and a number of different points (in particular at Mandalay, Prome, Bassein, and Rangoon). To take one example, one hundred miles of the Rangoon to Prome Railway line that were opened on 2 May 1877 consisted of the old Rangoon-Prome Road, which had been given to the railway construction engineers for this purpose. The bridges that had existed on the road, being made of wood, were now replaced with iron bridges that could support rail traffic. This last effort led the construction engineer to argue that building railway lines over normal provincial roads was an exercise in doubtful economy. Although a road bed built for cart traffic might support rail traffic, gradients, curves, and banks had to be remade to conform with requirements. ${ }^{16}$

As was true of the pre-colonial kingdom, a certain governmentality regarding popular movement influenced policies towards the railways and the feeder roads that serviced them. Certain acts of legislation, such as the Village Act that tied down the Burmese to their local village circle under the watchful eye of the village headman, get a great deal of attention, but scholars have paid little attention to the government road construction that appears to have been designed to discourage free movement of Burmese if not general mobility altogether.

In Burma, the British turned the roads into what some scholars have called "technologies of standardization and control" in which certain roads became the single "institutionalized route through the landscape" in order to focus all economic activity on the export economy 
(Harvey 2006: 131, citing Wilson 204, n.p.). Colonial engineering and equipment was put to work to ensure that when Burmese moved they did so only when, how, and by what routes the government wished. Through the army and then through the Public Works Department, the colonial government physically reconstructed the Burmese landscape, both in building the railways and in ruining alternative forms of transport, sometimes by design but also by accident as well. Before motor vehicles, for example, most potential road traffic was viewed as being within indigenous hands and it was best to redirect this traffic to feed the railway, which by 1902 had become a private company, but one upon which the colonial state was heavily dependent. Roads built in the west were thus built to feed the river traffic and roads built in the east were merely feeder roads of short length that forced people to take their goods to the railway stations (Maung Shein 1964: 38). While that effort was purposeful, there are also examples of where the British ruined alternative transportation accidentally as well. British water engineering works, for example, which had been intended to aid irrigation in the eastern part of the colony, made local rivers un-navigable, ruining port towns along the way. By the time this work was over, Curzon's vision had become a reality - Burma really did only have two great transportation avenues, the Irrawaddy River in the west and the railway in the east.

We have a fairly good understanding of the transportation history of Ghana since World War I because of the substantial secondary literature devoted to it by contemporary historians. ${ }^{17}$ Ghana saw the introduction of new motor vehicles that increased popular mobility, employment as locomotive drivers and later as motor vehicle entrepreneurs. ${ }^{18}$ Much of this colonial era of mobility opportunity was due to the nature of the Ghanaian economy. Cocoa farmers used the profits from their sales to buy lorries that could take the cocoa to buying agents. Some of these lorries and their Ghanaian owner-drivers can be seen in Figure 3. At first this meant going to the railways, but soon motor vehicles were taking this directly to the port. This process, in which Africans operated motor vehicles independently and developed a culture of mobility around it, has been called "African automobility" (Hart 2015).

17 The deadline for the submission of present article, prevented prior access to Jennefer Hart;s forthcoming book on Ghanaian mobility (Hart 2016).

18 While this has conferred prestige in Ghanaian society, something that has persisted into the present, this status is somewhat ambiguous (Klaeger 2009: 226). 


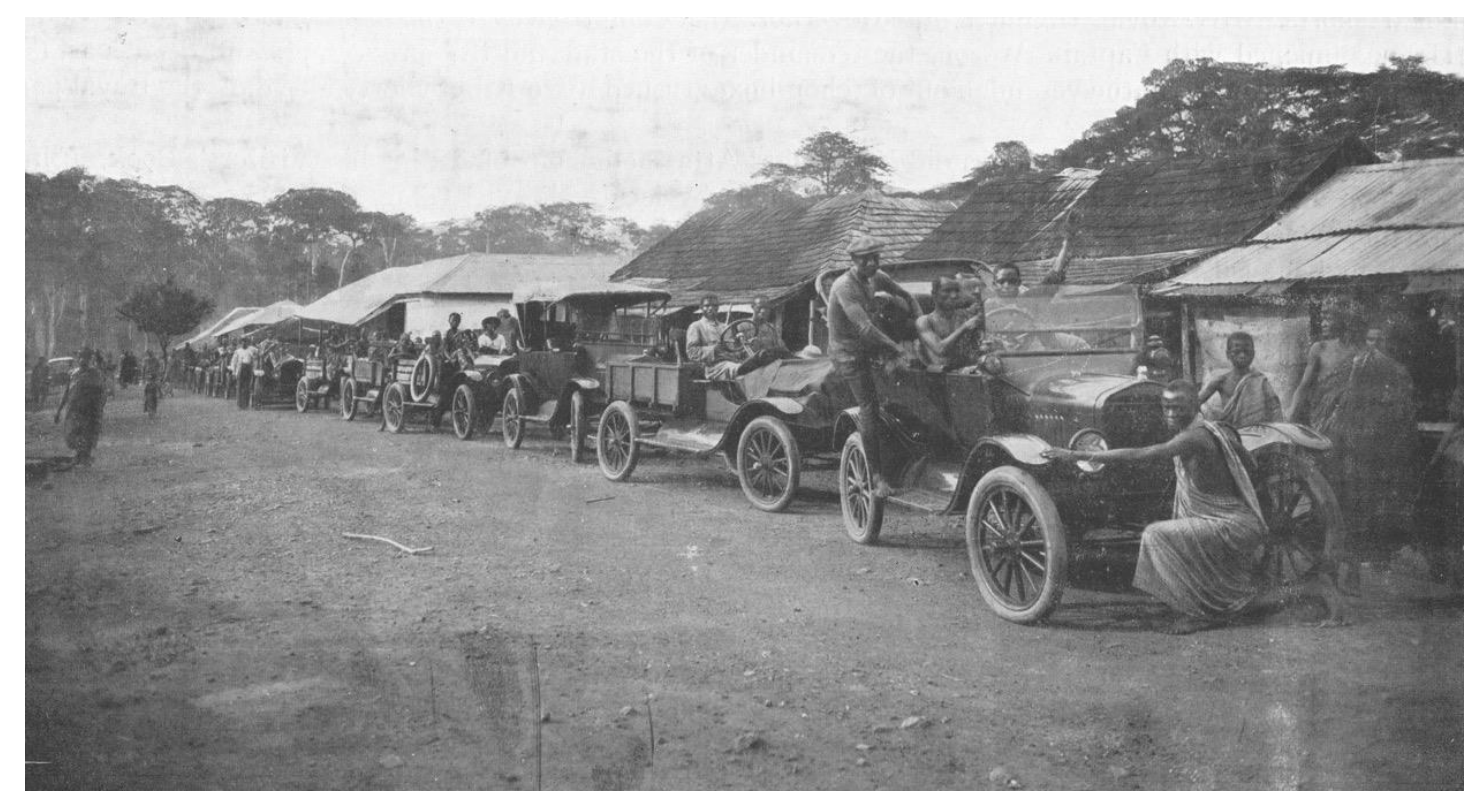

Figure 3: Photograph of cocoa lorries waiting to load in the mid-1920s (reproduced from Government of the Gold Coast 1925, p. 124).

It would be an overstatement not to admit that there were no colonial laws or officials who sought to control how Africans used transport, for there were and they did (Hart 2015). Often this was over safety concerns or because it challenged European notions of how a vehicle should be used. What was apparently not curtailed by government intervention, however, was autonomous indigenous mobility per se. Admittedly, the colonial government in Ghana was mainly concerned at first with railway development as this was essential for the gold mines, but they still encouraged road building (although indigenous people would have to do the work on their own). In the colonial period, these feeder and connecting roads were built on the basis of local knowledge, with an eye to their being suitable for human porterage and they relied upon local resources for materials. Just as many of these colonial-era roads were not suitable to motor traffic at all, many of the roads constructed today between communities remain un-motorable to modern buses (Ntewusu \& Nanbigne 2015: 197).

Although motorized transport, as mentioned above, became available from the 1920s, this mode of transport predominated in the south while the north, because of the topography and the fact that there was greater poverty in the north, the cheaper bicycle predominated in the north (Ntewusu \& Nanbigne 2015: 201). As with the colonial state, the modern Ghanaian government has actively promoted mobility and popular access to transport. Samuel Ntewusu has pioneered scholarship on transportation in subnational areas of Ghana with work mainly examining districts in Northern Ghana. Ntewusu and Edward Nanbigne have shed light on the Ghanaian government's role in making cheaper forms of transport available to larger numbers of people in the country. This began in the early 1960s with the government's encouragement to Yugoslavia to open a motorcycle plant in the northern town of Tamale; although it did not materialize the socialist nation did open up shops in northern Ghana to sell cheap motorcycles. More recently, in the last ten years, the government has developed a programme to promote the use of motor tricycles. This was begun in December 2012 with the Community Motor Tricycle Project to train 120,000 local youth how to use a special kind of 
motor tricycle, known as the motor king, and the following year began distributing tricycles as well (Ntewusu \& Nanbigne 2015: 201).

By contrast, the Burmese saw from the beginning of the colonial-era restrictions on the use of the vehicles that had historically allowed them the limited mobility they had exercised because of the equally limited oversight of the state on travel within the country. Colonial laws in Burma completed the work begun by the Public Works Department in eradicating the autonomy of traditional, indigenous means of on-and-off-the-road cross-country transport. One was the requirement that indigenous carts that wished to access the new government feeder roads wrap their wheels with a three- inch wide iron rim, known as the tyre (Scott 1924: 317). Indigenous cartwheels were until this time slab wheels, solidly built, not hollowed out and rimmed or spoked. An example of one type of slab wheel (Burmese, kya-bi, literally, slab + wheel) can be viewed in Figure 4. Such a wheel either solid or was constructed out of several pieces of wood fastened together and cut in the shape of a circle. The slab wheel was also convex-sided, being thickest at the centre and then 'tapered' out to the thinner edges of the wheel. For this reason, the slab wheel was superior to the spoked wheel during rainy and muddy conditions, especially when roads were in actually muddy wheel-tracks. Since the wheel was thinner around the edges and there were no crevices, as a spoked wheel would provide, such wheels moved through mud much more easily than would spoked wheels (Nisbet 1901: 1.377-378; Shway Yoe 1997: 81; Ferrars \& Ferrars 1900: 138; Scott 1924: 317; Williams 1922: 136).

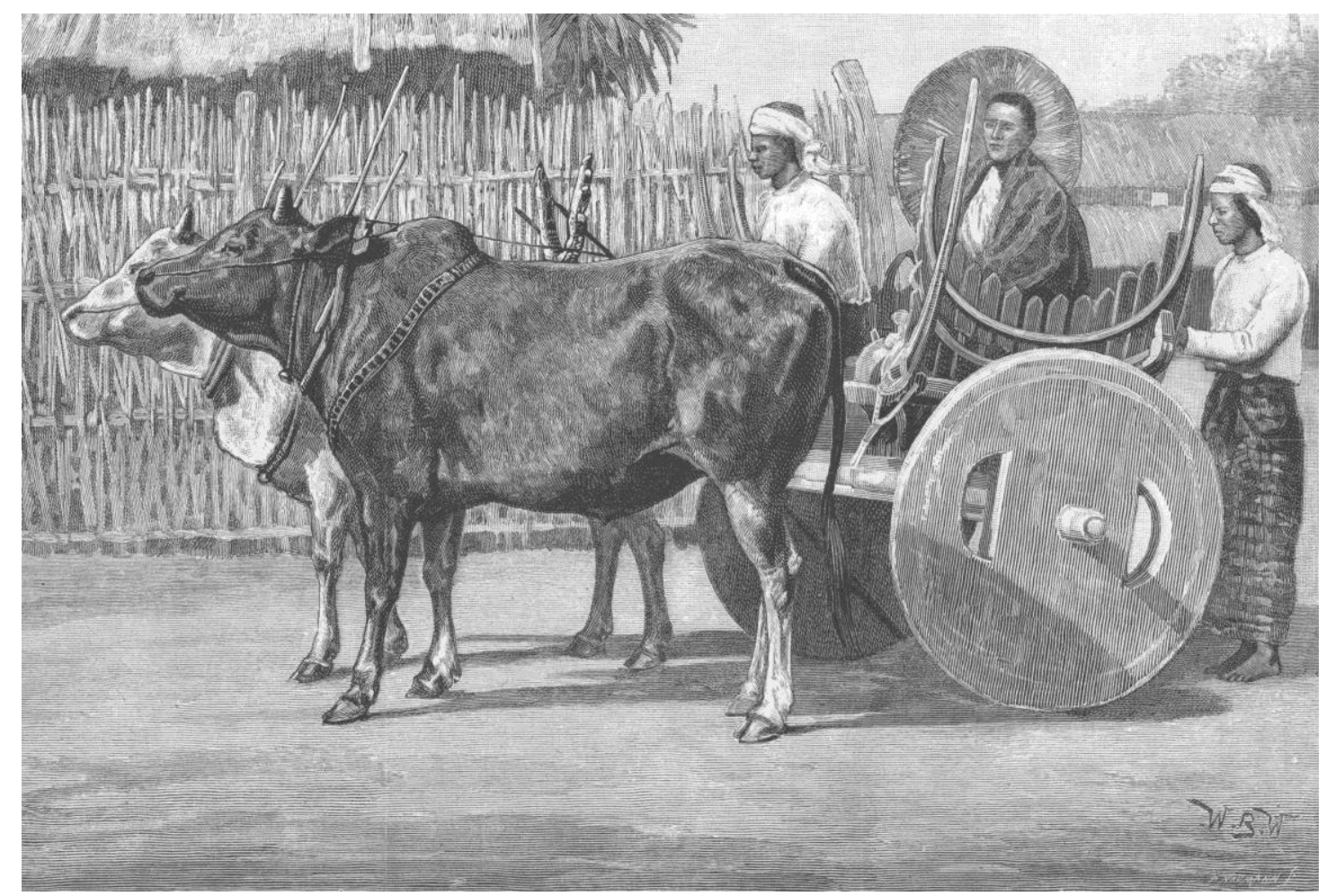

Figure 4: Pre-colonial Burmese cart with one type of slab-wheel, published in the 'Illustrated London News', 22 June 1889 (Author's private collection)

Slab wheels were very much disliked by colonial authorities because they were heavy and jagged and thus did damage to the new metaled roads the British had built. These roads were 
sometimes glazed over with stone (including the green stone sometimes used as ballast by ships originating in Europe), but "mostly with balls of burned brick apt to be easily pulverized during the hot season" (Nisbet 1901: 1.376-377). As one observer described them, "the tendency of cart bullocks to follow in a worn track causes the road surface to be worn in two deep furrows, while the metaled surface in the middle remains intact" (Scott 1924: 316). The addition of metal tyres it was argued would prevent this damage. Indigenous people had a choice of either not adding the tyres, which meant they could not bring goods or foodstuffs to the railways, which were now the only show in town, or adding the tyres and getting access to trade at railheads, but abandoning autonomous travel on muddy rural paths. Most chose the former and indigenous carts' solid wheels gave way to spoked wheels, which were no longer a problem for the feeder roads, but were problematic on pathways (Nisbet 1901: 1.376-377).

As we have seen already with engineering, the colonial state excelled at realizing desires it and pre-colonial ruling elites had always had to exert oversight and control on popular mobility. Administrative mechanisms lent data gathering and registration tools to aid the process of immobilizing indigenous transportation that was autonomous of colonial oversight. First, carts and wagons were enumerated. Second, with the colonial erection of municipalities, carts which were available for "hire in urban districts" had to be licensed. Third, with enumeration and licensing, it became possible to force traditional Burmese cart owners and operators to undertake the required changes to their vehicles for otherwise they would be denied access to the road. According to Nisbet, the changes to the road system saw an "enormous" increase in the production and use of indigenous carts (Nisbet 1901: 1.379).

But this was not the case. The "indigenous carts" referred to after licensing were in fact a new kind of cart, rebuilt to European-imposed specifications. They were not the old versions that now rapidly disappeared in all but the most out of the way places (Shway Yoe 1927: 81). Unfortunately, unlike the latter that were very well suited for all-terrain use, the new wheels were not. As a result, there were more indigenous carts now, but their use was limited to the semi-paved and metaled roadways that fed the railways. Commercial traffic and even human movement lost its autonomy and now was directed almost entirely in the direction of easily monitored government or government-aligned transportation networks, the Irrawaddy River (dominated by the Irrawaddy Flotilla Company) and the railway network (a Burma Railways monopoly). Broadly, these changes to transportation under colonial rule were consistent with those desired by, but beyond the capacity of, the pre-colonial kingdom in Burma.

These monopolies would be challenged in the late colonial period from many quarters. More economically and politically empowered Burmese tore away at these monopolies from the 1920s. From the 1930s, road competition and the building by the colonial state of new roads also began to take off, but with a carrying capacity nowhere near that which remained in the hands of the IFC and the Burma Railways, the latter becoming again in 1928 a government-owned enterprise. But these roads, building on the laws already in place for application against indigenous carts, were the home of motorcars and not ox-carts. As transportation sped up, reliance on the tediously slow traditional carts was fast becoming 
economical anyway. ${ }^{19}$ While urban-dwelling Burmese would own and use motorcars themselves, the motor car did not provide the same kind of freedoms that indigenous carts and un-metaled roads had provided because of dependence on fuel, the provision of which could be more easily controlled by the colonial state than the monitoring or the entire transportation network. Control of access to fuel, to the purchase of automobiles, and access to major roads represented one means of controlling mobility that carried into post-colonial Burma. Ultimately, Ne Win would introduce in 1962 more direct and formal restrictions on freedom of movement (Turku 2016: 16) that would severely restrict mobility among Burmese for the next half century.

At the end of the colonial period, Burma had deeply rooted controls over movement beyond locales and Ghana had free, both politically and physically, movement of people. To briefly touch on what are long-term and complicated developments, the first of the two states veered off towards military rule and authoritarianism by the 1960s. The other, after a number of failed efforts at authoritarian and military rule in the 1960s to 1992, became one of West Africa's strongest democracies. In fact, Ghana is regularly referred to as the poster-child for Democracy in West Africa, Africa's "model democracy" and a host of other referents commenting positively on its democratic experience (Boafo-Arthur 2008). To assert that preexisting, pre-colonial government attitudes to movement and mobility ensured that modern, independent Ghana and Burma would have the contemporary regimes that they have today would be reductionist. To suggest so was not the intention of this article. Instead, it is suggested, there was a continuity in how this governmentality became embedded in evolving attitudes towards what today would fall under the heading of public transportation infrastructure.

\section{Conclusion}

The continuity in approaches to movement and transportation between pre-colonial and colonial West Africa and Southeast Asia, as examined in the cases of Ghana and Burma contribute in part to an explanation of the political trajectory of these states after independence. Ghana has seen postcolonial political conditions with weak central control over localities and although from the 1990s it has had a relatively healthy Democracy, the Democratic record has been spotted for a few years at a time by experiments in authoritarian rule and number of military coups and even military rule of no more than a few years in length. It could be said that despite political instability from the 1950s to 1992, authoritarian traditions were very weak and unstable and certainly controls on local movement were even weaker. By contrast, Burma has seen traditions of efforts to assert very tight central control over localities and where it has not had military rule or predominant military control it has seen authoritarianism.

Despite British rule and a similar focus in the economy on the export of primary agricultural produce (cocoa in one and rice in the other) and mineral and precious metal extraction (gold in Ghana and silver, zinc, and bauxite in Burma), the policies of both colonial states towards popular mobility in their respective charges could not have been more

19 Williams described Burmese ox-carts as "terribly slow conveyances" and estimated their speed at about two miles an hour, with a daily tally of ten miles (Williams 1922: 140). 
different. It is unclear whether a great many factors contributed to or were symptomatic of their respective negative (Burma) or positive (Ghana) orientations towards mass mobility. For example, both Burma and Ghana experienced a series of very serious Anglo-indigenous wars but whereas Burma's final conquest led to a counter-insurgency campaign with prolonged and very significant controls on personal freedoms and movement (the Village Act), this did not occur in Ghana. Was this difference due to the particular commanders involved in the war and suppression or was it due to the long-term local context, one in which the British listened to the indigenous elites with whom they collaborated in suppression, men like the famous Kinwun Mingyi who themselves had been administrative officials in control of movement (this official, who became an adviser to the colonial regime, had in earlier days been in charge of a border outpost and later the Chief Minister of the court)? We might also ask if there was a difference in the way the Colonial Office and the Indian Office approached colonial rule and if their influence had some bearing on the colonial forces that suppressed the Ashanti and Burmans respectively.

Certainly one factor was the pre-colonial culture of mobility. The pre-colonial kingdoms, not the colonial states, helped to set the template for government attitudes towards popular mobility for the post-colonial societies that followed. As examined here, Burma is the model of a society that was ruled by royal courts and a colonial state that were mass mobilityaverse. The existence of resulting controls on movement, however ineffective regarding domestic roads, may help to explain the significant role of Chinese overland traders to some degree, but more particularly the important role of ethnic minorities like the Shan in managing pre-colonial and colonial trans-border trade. By contrast, the Ashanti Kingdom and the colonial state that followed might be characterized more as mobility-encouraging states. Contemporary Ghana and Burma have certainly inherited these very different approaches to individual freedoms and controls on individual movement, one that was very empowering and the other which was very restrictive and which some very clearly rebelled against. Clearly, the extension of British rule in the Gold Coast over Ashanti was partially welcomed by a least some sections of the indigenous population because it offered through road construction, repair, and maintenance to provide the same kind of service, with an intensification of investment and capacity that the pre-colonial kingdom had provided. In Burma, the same kinds of direct and indirect controls on movement were applied by the colonial state as had been under pre-colonial rule, with the opposite reaction - many did not like it. To oversimplify a complex debate and diverse and rich literature, the question should focus not on state-space or non-state-space, but on what happens in that space. Another assertion is that we really need to give late early modern states in Africa and Southeast Asia their peculiar due administratively, intellectually, and militarily rather than lump them together as I have done in the present article for coherence and clarity, as part of the precolonial kingdom. On-going developments in them set them apart as they do in Europe, both from their classical and even from their early-early modern predecessors.

\section{References}

Agnew, John (1994), "The territorial trap: The geographical assumptions of international relations theory", Review of International Political Economy 1: 53-80. 
Ahuja, Ravi (2009), Pathways of empire: Circulation, public works' and social space in colonial Orissa (c. 1780-1914). Hyderabad: Orient Blackswan.

Anuman, Phya (1987), "Travel by bullock carts", in Phya Anuman Rajadhon. Some traditions of the Thai and other translations of Phya Anuman Rajadhon's articles on Thai customs. Bangkok: Thai Inter-Religious Commission for Development and Sathira Koses Nagapradipa Foundation. Pp. 173-6.

Aungwom, Edlyne F. (2001), "The military, ethnicity and democracy in Nigeria." Journal of Social Development in Africa 16.2: 92-110.

Ba Thann Win (1976), Highways and major bridges of Burma. Rangoon: Nay Yee Yee Press.

Bayly, C. A. (1996), Empire and information: Intelligence gathering and social communication in India, 1780-1870. Cambridge: Cambridge University Press.

Beemer, Bryce (2004), "Slave-gathering warfare and cultural exchange in Burma, Thailand, and Manipur." Unpublished PhD dissertation, University of Hawaii.

Boafo-Arthur, Arthur (2008), Democracy and stability in West Africa: The Ghanaian experience. Uppsala: Department of Peace and Conflict Research, Uppsala University $\&$ the Nordic Africa Institute.

Bock, Carl (1986), Temples and Elephants: Travels in Siam in 1881-1882. Singapore: Oxford University Press.

Brackenberry, Henry (1874), The Ashanti War: A narrative. 2 Vols. Edinburgh: William Blackwood and Sons.

Bruijn, Mirjam de, Han van Dijk, \& Rijk van Dijk (2001), "Cultures of travel: Fulbe pastoralists in Central Mali and Pentecostalism in Ghana", in Mirjam de Bruijn, Rijk van Dijk, \& Dick Foeken (eds), Mobile Africa: Changing patterns of movement in Africa and beyond. Leiden: Brill. Pp. 63-88.

Buchanan, Francis (1795), "Burma Journal.” MSS Eur C. 12, British Library Asia and Africa Collection, London.

Burney, Henry (1842), "On the population of the Burman Empire." Journal of the Statistical Society of London 4.4: 335-47.

Cartwright, H. A., and O. Breakspeare (1910), Twentieth century impressions of Burma: Its history, people, commerce, industries, and resources. London: Lloyd's Greater Britain Publishing Company.

Charney, Michael W. (1997), "Shallow-draft boats, guns, and the Aye-ra-wa-ti: Continuity and change in ship structure and river warfare in precolonial Myanma", Oriens Extremus 40.1: 16-63.

Cooper, Frederic (1992), "The dialectics of decolonization: Nationalism and labor movements in postwar Africa", CSST Working Paper no. 84: 1-24.

Cooper, Frederic \& Stoler, Ann Laura (eds) (1997), Tensions of empire: Colonial cultures in a bourgeois world. Berkeley/Los Angeles/London: University of California Press.

Cox, Hiram (1821), Journal of a residence in the Burmhan Empire, and more particularly of the court of Amarapoorah. London: John Warren \& G. \& W. B. Whittaker.

Crawfurd, John (1829), Journal of an embassy from the Governor-General of India to the court of Ava in the year 1827. With an Appendix by Professor Buckland and Mr Clift. London: Henry Colburn.

Croswaite, C. (1912), The pacification of Burma. London: E. Arnold.

Cuming, E. D. (1919), In the shadow of the pagoda: Sketches of Burmese life and character. London: W. H. Allen \& Co. 1897.

DMY. Dutiya-maha-ya-zawin-daw-gyì. Mandalay: n. p.

Doormont, Michel R. (2001), "An overview of Dutch relations with the Gold Coast in the light of David van Nyendael's mission to Asante in 1701/'02." Unpublished conference 
paper for Dutch Ghanian Relations: Past and Present, The Hague [www.oprit.rug.nl/doormont].

Edgerton, Robert B. (2010), The fall of the Asante Empire: The hundred-year war for Africa's Gold Coast. New York: Simon and Schuster.

Esler, Anthony (1996), The human venture: The globe encompassed - A world history since 1500. New York: Prentice Hall.

Ferrars, Max \& Bertha Ferrars (1900), Burma. London: S. Low, Marston \& Co.

Foucault, Michel (1991), "Governmentality." In Graham Burchell, Colin Gordon, and Peter Miller (eds.). The Foucault effect: Studies in governmentality with two lectures by and an interview with Michael Foucault. Chicago: The University of Chicago Press. Pp. 87104.

Freeman, Richard Austin (1898), Travels and life in Ashanti and Jaman. London: A. Constable \& Co.

Freeman, Thomas Birch (1844), Journal of various visits to the Kingdoms of Ashanti, Aku and Dahomi, in Western Africa. 2nd ed. London: John Mason.

Furnivall, J. S. (1948), Colonial policy and practice: A comparative study of Burma and the Netherlands India. Cambridge: Cambridge University Press.

Gould, P. R. (1960), The development of the transport pattern in Ghana. Evanston: Dept. of Geography, Northwestern University.

Government of Burma (1957), The Burma hand-book of rural self government. 2 vols. Rangoon: Superintendent, Government Printing and Stationery, Union of Burma.

Government of the Gold Coast (1925), Visit of His Royal Highness the Prince of Wales to the Gold Coast Colony. Accra: Government Printing Office.

Hart, Jennifer (2015), “Automobility, technopolitics, and African histories of technology-inuse in twentieth century Ghana." Paper presented for Technology's Stories: Past and Present.

Hart, Jennifer (2016), Ghana on the go: African mobility in the age of motor transportation. Bloomington: Indiana University Press [in press].

Harvey, G. E. (1983), History of Burma: From the earliest times to 10 March 1824: The beginning of the English conquest. New York: Octagon Books.

Harvey, Penelope (2005), "The materiality of state-effects: An ethnography of a road in the Peruvian Andes.” In Krohn-Hansen, Christian \& Nustad, Knut G. (eds), Anthropology, culture and society: State formation: Anthropological perspectives. With a foreword by Bruce Kapferer. London: Pluto Press. Pp. 123-41.

Headrick, Daniel R. (1967), Tools of empire: Technology and European imperialism in the nineteenth century. Oxford: Oxford University Press. 1981.

Herbst, J. (2000), States and Power in Africa. Princeton, J.J.: Princeton University Press.

Hman-nan maha-ya-zawin-daw-gyi. 3 vols. Yangon.

Jedwab, Remi \& Moradi, Alexandre (2011), "Transportation infrastructure and development in Ghana", PSE Working Papers n. 2011-24.

Jeffries, Richard (1978), Class, power, and ideology in Ghana: The railwaymen of Sekondi Takoradi. Cambridge: Cambridge University Press.

Keane, Augustus H. (2006), "Extracts related to Burma drawn from Stanford's compendium of geography and travel: Asia", SOAS Bulletin of Burma Research 4.1: 55-58.

Klaeger, Gabriel (2009), "Religion on the road: The spiritual experience of road travel in Ghana", in Jan-Bart Gewald, Sabine Luning, and Klaas van Walraven (eds), The speed of change: Motor vehicles and people in Africa, 1890-2000. Leiden: Brill. Pp. 212-31.

Koenig, William (1990), The Burmese polity, 1752-1819: Politics, administration, and social organization in the Early Konbaung Period. Ann Arbor: Center for South \& Southeast Asian Studies. 
Krohn-Hansen, Christian \& Nustad, Knut G. (eds) (2005), Anthropology, culture and society: State formation: Anthropological perspectives. With a foreword by Bruce Kapferer. London: Pluto Press.

Lieberman, Victor (2003), Strange parallels. Volume 1: Integration of the mainland Southeast Asia in global context, c. 800-1830. Cambridge: Cambridge University Press.

Lieberman, Victor (1993), "Was the seventeenth century a watershed in Burmese history?", in Anthony Reid (ed.). Southeast Asia in the Early Modern Era: Trade, power, and belief. Ithaca, New York: Cornell University Press. Pp. 214-49.

Lonsdale, R. (1881), "Memorandum of Prince Buaki's journey from Elina to Accra, with notes on the condition of the roads, etc, $13^{\text {th }}$ to $22^{\text {nd }}$ September 1881 ", in House of Commons Command Paper 3386, "Further Correspondence on the Affairs of the Gold Coast", pp. 4-5.

Luntinen, Pertti (1996), Railway on the Gold Coast: A meeting of two cultures - A colonial history. Helsinki: Suoma-Ainen Tiedeakatemia.

Malcom, Howard (1839), Travels in South-Eastern Asia, embracing Hindustan, Malaya, Siam, and China; With notices of numerous missionary stations, and a full account of the Burman Empire. $2^{\text {nd }}$ ed. 2 vols. Boston: Gould, Kendall, and Lincoln.

Malcolm, Howard (1997), Travels in the Burman Empire. Bangkok: Ava House. Reprint.

Mann, Michael (1993), The sources of social power. 2 vols. New York: Cambridge University Press.

Masquelier, A. (2002), "Road mythographies: Space, mobility and the historical imagination in postcolonial Niger", American Ethnologist 29: 829-55.

Michalopolous, Stelios \& Papaioannou, Elias (2011), "Divide and rule or the rule of the divided? Evidence from Africa." NBER Working Paper 17184 (Cambridge, MA: National Bureau of Economic Research).

Migdal, J. (1988), Strong societies and weak states: State-society relations and state capabilities in the Third World. Princeton, N. J.: Princeton University Press.

Murphy, E. Jefferson (1972), History of African civilisation. New York: Crowell.

The Myanmar-English dictionary (1993), Yangon, Myanmar: Union of Myanmar Ministry of Education. Department of the Myanmar Language Commission.

"Nidana Ramadhipati-katha." N.D. Translated by H. L. Shorto. TMs [photocopy], private collection, Dr. Victor B. Lieberman, Department of History, University of Michigan, Ann Arbor, Michigan.

Nisbet, John (1901), Burma under British rule-and before. 2 vols. London: Archibald \& Constable.

Ntewusu, Samuel Aniegye (2014), "The road to development: The construction and use of 'the Great North Road' in Gold Coast Ghana." Africa Studies Centre Leiden Working Paper 114 (Leiden African Studies Centre).

Ntewusu, Samuel Aniegye (2011), "Settling in and holding on: A socio-economic history of northern traders and transporters in Accra's Tudu, 1908-2008" (PhD dissertation: Leiden University).

Ntewusu, Samuel Aniegye \& Nanbigne, Edward (2015), "So be nya dagna? ('Is someone injured?'): The evolution and use of tricycles in Tamale, northern Ghana." In Akinyinka Akinyoade \& Jan-Bart Gewald (eds), African roads to prosperity: People en route to socio-cultural and economic transformations. Leiden: Brill. Pp. 197-211.

Osterhammel, Jürgen (1997), Colonialism: A theoretical overview. Translated from the German by Shelley L. Frisch. Kingston: Ian Randle Publishers.

Perbi, Akosua (1992), "Mobility in pre-colonial Asante from a historical perspective", Ghana Research Review 7.1\&2: 72-86. 
Reid, Anthony (1988), Southeast Asia in the age of commerce. Volume I. The lands below the winds. New Haven, Connecticut: Yale University Press.

Reid, Anthony (1993a), Southeast Asia in the age of commerce. Volume II. Expansion and crisis. New Haven, Connecticut: Yale University Press.

Reid, Anthony (1993b), "Islamization and Christianization in Southeast Asia: The critical phase, 1550-1650", in Idem (ed.), Southeast Asia in the Early Modern Era: Trade, power, and belief. Ithaca: Cornell University Press. Pp. 151-79.

Rigg, Jonathan (2002), "Roads, marketization and social exclusion in Southeast Asia: What do roads do to people?" Bijdragen tot de Taal-, Land- en Volkenkunde 158,4: 619-20.

Scott, James C. (1998), Seeing like a state: How certain schemes to improve the human condition have failed. New Haven: Yale University Press.

Scott, James C. (2009), The art of not being governed: An anarchist history of upland Southeast Asia. New Haven: Yale University History.

Scott, J. George (1921), Burma: A handbook of practical information. 3rd edition. London: Daniel O'Connor.

Shway Yoe (J. George Scott) (1927), The Burman: His life and notions. London: MacMillan \& Co.

Shein, Maung (1964), Burma's transport and foreign trade in relation to the economic development of the country (1885-1914). Rangoon: Department of Economics, University of Rangoon.

Sivasundaram, Sujit (2013), Islanded: Britain, Sri Lanka, and the bounds of an Indian Ocean colony. Chicago: The University of Chicago Press.

Sturgis, Sam (2015), "How overlooked colonial railways could revolutionize transportation in Africa", The Atlantic. http://www.citylab.com /commute / 2015 /02 / how-overlookedcolonial-railways-could-revolutionize-transportation-in-africa/385056/

Symes, Michael (1800), Account of an embassy to Ava. London.

Symes, Michael (1955), Journal of his second embassy to the Court of Ava in 1802. Edited, with introduction and notes by D. G. E. Hall. London: George Allen \& Unwin.

Than Tun (1983), "Paya Lanma (Lord's highway) over the Yoma (Yakhine Range)." Journal of Asian and African Studies 25: 234-41.

Than Tun (ed.) (1984-90), The royal orders of the Kings of Burma. 10 vols. Kyoto: Center for Southeast Asian Studies. Kyoto University.

Thant Myint-U (2001), The making of modern Burma. Cambridge: Cambridge University Press.

Tin, Ù. (1967), Kòn-baung-zet Maha-ya-zawin-daw-gyì. Vol. II. Rangoon: Hanthawaddy Press.

Trager, Frank N. \& Koenig, William J. (eds. \& [Koenig] tr.). (1979), Burmese Sit-tàns 17641826: Records of rural life and administration. With the assistance of Yi Yi. Tucson, Arizona: University of Arizona Press.

Tsey, Komla (2013), From head-loading to the iron horse: Railway building in colonial Ghana and the origins of tropical development. Mankon: Langaa Research \& Publishing.

Turku, Helga (2016), Isolationist states in an independent world. London: Routledge.

Turner, Alicia (2014), Saving Buddhism: The impermanence of religion in colonial Burma. Honolulu: University of Hawai'i Press.

Wilks, Ivor (1975), Asante in the nineteenth century: The structure and evolution of a political order. Cambridge: Cambridge University Press.

Wilks, Ivor (1992), "On mentally mapping Greater Asante: A study of time and motion", The Journal of African History 33.2: pp. 175-190. 
Williams, A. H. (1922), Afoot and afloat in Burma. Washington, D. C.: Review and Herald Publishing Association.

Williamson, Thora (2000), Gold Coast diaries: Chronicles of political officers in West Africa. Edited by Anthony Kirk-Greene. With a forward by Richard Rathbone. London: The Radcliffe Press.

Wilson, F. (2004), "Towards a political economy of roads: Experiences from Peru", Development and Change 35.3: 525-46.

Wilson, Horace Hayman (comp.) (1827), Documents illustrative of the Burmese War. Calcutta: Government Gazette Press.

Wolters, O. W. 1982. History, culture and region in Southeast Asian perspective. Singapore: Institute of Southeast Asian Studies.

Wrangham, E. 2010. "An African road revolution: The Gold Coast in the Great War." The Journal of Imperial and Commonwealth History 31: 1-18.

Young, Crawford. 1994. The African colonial state in comparative perspective. New Haven: Yale University Press. 